\title{
PENGEMBANGAN MODUL IPA TERPADU TIPE CONNECTED BERBASIS IQRA TEMA LINGKUNGAN PANTAI UNTUK MEMBERDAYAKAN KARAKTER RELIGIUS SISWA SMP/MTS KELAS VII SEMESTER II
}

\author{
Ambarsari Indraningrum ${ }^{1}$, Widha Sunarno ${ }^{2}$, Nonoh Siti Aminah ${ }^{3}$ \\ ${ }^{1}$ Program Studi Magister Pendidikan Sains FKIP Universitas Sebelas Maret \\ Surakarta, 57126, Indonesia \\ ambarsariindraningrum@student.uns.ac.id \\ ${ }^{2}$ Program Studi Magister Pendidikan Sains FKIP Universitas Sebelas Maret \\ Surakarta, 57126, Indonesia \\ widhasunarno@staff.uns.ac.id \\ ${ }^{3}$ Program Studi Magister Pendidikan Sains FKIP Universitas Sebelas Maret \\ Surakarta, 57126, Indonesia \\ nonoh_nst@staff.uns.ac.id
}

\begin{abstract}
Abstrak
Penelitian ini bertujuan untuk: (1) mengembangkan modul IPA terpadu tipe Connected berbasis Iqra tema lingkungan pantai untuk memberdayakan karakter religius siswa SMP/MTs Kelas VII Semester II; (2) mengembangkan modul IPA terpadu tipe Connected berbasis Iqra tema Lingkungan Pantai yang layak untuk memberdayakan karakter religius siswa SMP/MTs Kelas VII Semester II. (3) mengetahui efektivitas modul IPA terpadu tipe Connected berbasis Iqra tema lingkungan pantai untuk memberdayakan karakter religius siswa SMP/MTs Kelas VII Semester II. Penelitian ini merupakan penelitian pengembangan (Research \& Development / $R \& D$ ) oleh Thiagarajan (1974), pengembangan yang digunakan adalah model 4-D, dengan tahapan Define, Design, Develop, dan Disseminate. Sampel penelitian pengembangan meliputi:1) 2 validator ahli (ahli materi dan ahli media), 2 guru IPA, dan 2 teman sejawat, 2) sampel uji coba terbatas sejumlah 10 siswa kelas VIIB SMP Institut Indonesia Kutoarjo, dan 3) sampel uji lapangan operasional sejumlah 30 siswa kelas VIIA SMP Institut Indonesia Kutoarjo. Instrumen yang digunakan adalah angket, lembar observasi, dan tes. Uji coba pemakaian menggunakan one group pretest-posttest design. Analisis data yang digunakan pada tahap define adalah analisis data deskriptif, pada tahap design dengan analisis SK dan KD untuk menentukan desain awal modul, pada tahap develop analisis data hasil validasi modul, data respon siswa dan data pemberdayaan karakter religius berupa data angket yang dikonversi menjadi kategori kualitas dengan pedoman skor skala 4, dan pada tahap disseminate data yang didapatkan berupa data angket yang dikonversi menjadi kategori kualitas dengan pedoman skor skala 4. Berdasarkan analisis data diperoleh hasil penelitian sebagai berikut:1) modul IPA terpadu tipe Connected berbasis Iqra tema lingkungan pantai untuk memberdayakan karakter religius siswa memiliki ciri yaitu langkah pembelajaran pada modul disesuaikan pada langkah pembelajaran Iqra, dan mengintegrasikan karakter religius pada setiap tahapnya, 2) modul dikategorikan layak karena telah melalui beberapa uji kelayakan. Uji kelayakan modul dinilai oleh validator ahli (ahli materi dan ahli media), 2 guru IPA, dan 2 teman sejawat. Berdasarkan uji kelayakan modul memiliki kategori layak yang didukung dengan hasil perhitungan dengan rata-rata presentase sebesar $90 \%$ yang dikategorikan "sangat baik". Modul mendapatkan respon dari siswa dan guru dalam proses pembelajaran yang dinilai dari angket respon yang mengkategorikan modul sangat baik, serta didukung dengan hasil disseminate yang diserahkan pada 5 guru IPA yang mengkategorikan modul baik,3) efektifitas modul berbasis Iqra dengan tema lingkungan pantai untuk memberdayakan karakter religius siswa didapatkan $\mathrm{N}$-gain score sebesar 0, 58 untuk hasil belajar,serta pencapaian KKM didapatkan hasil 96,7\%. Sedangkan hasil angket siswa dan lembar observasi terhadap pemberdayaan karakter religius didapatkan ratarata keseluruhan nilai sebesar $85,3 \%$ yang dikategorikan "sangat baik" sehingga karakter religius dapat terberdayakan.
\end{abstract}




\section{Pendahuluan}

Undang-undang Nomor 20 Tahun
2003 menyebutkan bahwa pendidikan
merupakan usaha sadar dan terencana untuk
mewujudkan suasana belajar dan proses
pembelajaran agar siswa secara aktif mengembangkan potensi dirinya untuk memiliki kekuatan spiritual keagamaan, pengendalian diri, kepribadian, kecerdasan, akhlak mulia serta keterampilan yang diperlukan dirinya, masyarakat, bangsa, dan negara. Potensi diri manusia disebut juga fitrah manusia. Dengan demikian, pendidikan merupakan usaha sadar dan terencana untuk mewujudkan suasana belajar dan proses pembelajaran agar peserta didik secara aktif mengembangkan potensi dirinya (fitrah manusia) untuk memiliki kekuatan spiritual keagamaan dan seterusnya. Menurut Hasan (2006), upaya pendidikan disamping berusaha untuk mengembangkan potensi-potensi fitrah manusia, juga berusaha untuk menyelamatkan dan melindungi fitrah manusia, serta menyelaraskan langkah perjalanan fitrah yang diciptakan Tuhan pada manusia berupa naluri dengan rambu-rambu fitrah yang diturunkan Tuhan sebagai acuan hidup, yaitu agama dalam semua aspek kehidupannya. Dengan demikian, manusia dapat lestari hidup di atas jalur kehidupan yang baik dan benar.

Selanjutnya pada Pasal 1 ayat (2) dinyatakan bahwa pendidikan nasional adalah pendidikan yang berdasarkan Pancasila dan Undang-undang Dasar Negara Republik Indonesia Tahun 1945 yang berakar pada nilainilai agama, kebudayaan nasional Indonesia dan tanggap terhadap tuntutan perubahan zaman. Konsep penting ini juga turun ke dalam UU No. 14 Tahun 2005 tentang guru dan dosen, seperti pada Pasal 6 dan 7. Bahkan dikembangkan menjadi pilar pertama dalam pembelajaran sebagaimana pada tabel 1 berikut:
Tabel 1. Pilar Pertama Pembelajaran

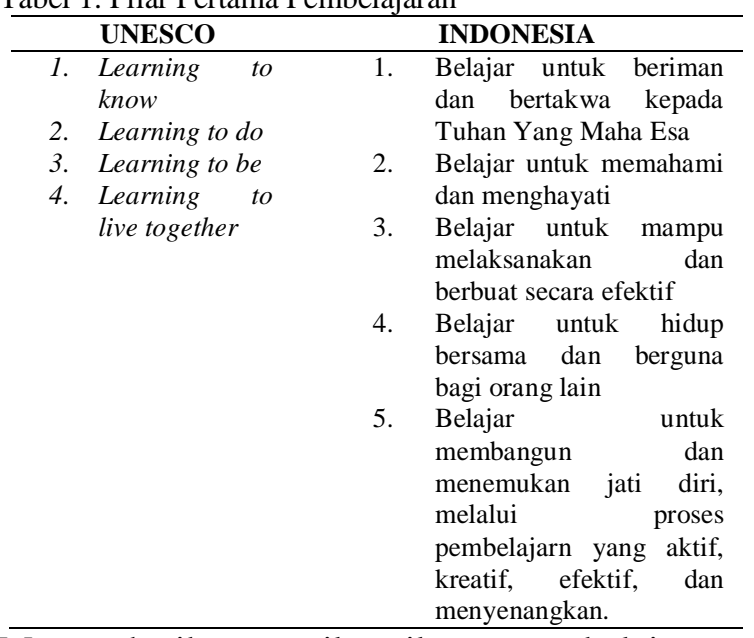

Memperhatikan pilar-pilar pembelajaran tersebut, maka setiap pendidik/guru (bidang apa saja) di sekolah/madrasah harus mengarahkan belajar siswa kearah belajar untuk beriman dan bertakwa kepada Tuhan Yang Maha Esa di samping learning to know, to do, to be, dan learning to live together. Hal ini menggaris bawahi perlunya pengintegrasian iman dan takwa (imtak) dengan iptek. Pengintegrasian tersebut, menurut Tafsir (2008), dapat dilakukan melalui integrasi dengan materi pelajaran, model pembelajaran, proses pembelajaran, dalam memilih bahan ajar dan integrasi dalam memilih media pembelajaran.

Materi pembelajaran, model pembelajaran, maupun bahan ajar yang digunakan di SMP Institut Indonesia belum ada yang secara kontekstual berisikan karakter ketuhanan selain pada mata pelajaran pendidikan agama Islam. Integrasi iman dan takwa dalam setiap materi, model, proses, maupun bahan ajar yang digunakan di sekolah adalah salah satu amanat dari UUD 1945.

Model Pembelajaran Iqra merupakan salah satu model pembelajaran yang mengintegrasikan imtak dengan iptek. Model pembelajaran Iqra adalah suatu model pembelajaran yang mengajak peserta didik untuk aktif mengeksploitasi lingkungan yang ada di sekitar peserta didik. Peserta didik diajak untuk aktif berkegiatan misalnya percobaan, berdiskusi, meramalkan, memodelkan, dan sebagainya. Pada model pembelajaran Iqra, sebelum memulai 
pembelajaran peserta didik diajak untuk mengenal sifat-sifat Ketuhanan. Dengan demikian siswa akan sadar bahwa segala sesuatu atau ilmu yang dipelajari merupakan bukti ke-Esa-an Tuhan. Melalui pembelajaran Iqra peserta didik dituntun untuk dapat melihat atau membaca sesuatu yang telah diciptakan oleh Tuhan yang berupa alam semesta dan kekayaannya. Dengan pembelajaran seperti ini diharapkan peserta didik akan memahami bahkan menemukan konsep-konsep mata pelajaran pendidikan umum tanpa meninggalkan atau mengabaikan konsepkonsep Ketuhanan.

Melalui pembelajaran terpadu, siswa dapat memperoleh pengalaman langsung sehingga dapat menambah kekuatan untuk menerima, menyimpan, dan menerapkan konsep yang telah dipelajarinya. Dengan demikian, siswa terlatih untuk dapat menemukan sendiri berbagai konsep yang dipelajari secara menyeluruh (holistis), bermakna, autentik, dan aktif. Cara pengemasan pengalaman belajar yang dirancang guru sangat berpengaruh terhadap kebermaknaan pengalaman belajar bagi siswa. Pengalaman belajar yang lebih menunjukkan kaitan unsur-unsur konseptual akan menjadikan proses belajar lebih efektif. Kaitan konseptual yang dipelajari dengan sisi bidang kajian ilmu-ilmu yang relevan akan membentuk skema positif sehingga anak memperoleh keutuhan dan kebulatan pengetahuan. Perolehan keutuhan belajar, serta kebulatan pandangan tentang kehidupan, dunia nyata dan fenomena kehidupan nyata dapat direfleksikan melalui pembelajaran terpadu (Trianto, 2014: 7).

Ilmu Pengetahuan Alam (IPA) merupakan salah satu mata pelajaran yang dapat disajikan secara terpadu, yang diharapkan dapat digunakan sebagai sarana pencapaian amanat KTSP. Ilmu Pengetahuan Alam (IPA) berkaitan dengan cara mencari tahu tentang alam secara sistematis, sehingga IPA bukan hanya penguasaan kumpulan pengetahuan yang berupa fakta, konsep, atau prinsip tetapi lebih dari itu merupakan suatu proses inquiry.

\begin{abstract}
Peraturan Menteri Pendidikan
Nasional Nomor 41 Tahun 2007 tentang standar proses, perencanaan pembelajaran mensyaratkan guru pada satuan pendidikan untuk mengembangkan perencanaan
\end{abstract} pembelajaran. Pada konteks pembelajaran IPA terpadu, seorang guru dituntut untuk dapat menyusun dan mengembangkan perangkat pembelajaran IPA secara terpadu yang memadukan tiga bidang studi yaitu fisika, kimia, dan biologi. Melalui model pembelajaran IPA Terpadu memungkinkan proses kegiatan belajar mengajar (KBM) berlangsung secara efektif dan efisien.

Berdasarkan data Program for International Assesment of Student (PISA) tahun 2012, peringkat Indonesia hanya menduduki 60 dari 65 negara. Ada tiga aspek yang diteliti PISA, yaitu kemampuan membaca, matematika, dan sains. Nilai yang diperoleh siswa Indonesia untuk membaca (57), matematika (61), dan sains (60). Menurut studi tersebut, anak Indonesia masih rendah dalam kemampuan literasi sains diantaranya mengidentifikasi masalah ilmiah, menggunakan fakta ilmiah, memahami sistem kehidupan dan memahami penggunaan peralatan sains.

Berdasarkan hasil studi yang dilakukan oleh Trends in International Mathematics and Science Study (TIMSS) tahun 2011 dan dipublikasikan pada 11 Desember 2012, Indonesia berada di posisi ke40 dari 63 negara dan 14 negara bagian atau wilayah yang disurvei. Ada dua aspek yang diteliti TIMSS, yaitu matematika dan sains. Berdasarkan hasil studi tersebut nilai rata-rata siswa Indonesia untuk matematika adalah 386 atau turun 11 angka. Sementara itu untuk sains adalah 406 atau turun 21 angka dibandingkan dengan tahun 2007. Berdasarkan hasil studi PISA dan TIMSS, merupakan sebuah tantangan bagi calon guru dan guru IPA untuk membelajarkan IPA secara efektif kepada siswanya. Salah satu cara mewujudkannya adalah dengan menghubungkan fenomena IPA yang terjadi dikehidupan sekitar siswa, termasuk didalamnya yaitu pendidikan berbasis kearifan lokal. 
Berdasarkan hasil observasi terhadap SMP/MTs di sekitar lingkungan pantai kabupaten Purworejo, pembelajaran IPA di sekolah di sekitar lingkungan pantai masih belum mampu menjadi media sosialisasi untuk memberdayakan kesadaran siswa terhadap keberadaan pantai dengan segala potensinya. Pembelajaran masih memusatkan pada concept-minded dengan alasan agar mampu meluluskan siswa sebanyak-banyaknya pada Ujian Nasional. Pembelajaran IPA banyak diisi dengan kegiatan ceramah dan latihan soal. Selain masalah orientasi pembelajaran IPA, sebagian besar guru juga belum mampu mengemas perangkat pembelajaran IPA yang berbasis pada kondisi lingkungan sekitar. Bidang studi IPA yang diajarkan di SMP/MTs secara terpadu seharusnya mampu memberikan kesempatan kepada siswa untuk membangun pengetahuan dalam mengidentifikasi masalah di kehidupan sehari-hari yang mempunyai dasar IPA. Pada pembelajaran IPA maka alamlah yang seharusnya menjadi sumber utama pembelajaran. Buku penunjang yang digunakan hanyalah buku BSE dan didampingi oleh LKS yang didatangkan dari percetakan. Potensi buku di sekolah masih sangat kurang, apalagi buku ajar yang menunjang karakter religius, kebanyakan buku yang digunakan hanya menunjang pengetahuan kognitif siswa saja.

Buku BSE juga terdapat beberapa kelemahan, yaitu: 1) cakupan materi buku kurang terperinci dan materi IPA tidak disesuaikan dengan keadaan lingkungan sekitarnya, 2) hanya terdapat materi ajar, latihan soal, rangkuman, soal evaluasi, dan belum terdapat contoh berupa gambar lingkungan pantai secara kontekstual di setiap pokok bahasan, 3) terdapat contoh praktikum, tetapi masih terlalu sederhana dan tidak mencakup keseluruhan materi. Kegiatan praktikum hanya membidik etos kerja, rasa ingin tahu, mengembangkan kecakapan sosial, dan vokasional siswa, dan 4) bahasa pada buku ajar masih sulit untuk dipahami siswa.

LKS juga terdapat banyak kelemahan, yaitu: 1) LKS kurang menarik karena dicetak menggunakan kertas buram dan hanya terdapat warna pada sampul, 2) materi yang disajikan masih terlalu banyak dengan penjelasan yang kurang terarah pada topik bahasan, 3) bahasa yang digunakan membuat siswa sulit memahaminya, 4) tidak adanya contoh mengenai lingkungan pantai berupa gambar yang dapat memperkaya pengetahuan siswa, 5) terdapat banyak soal baik pilihan ganda dan uraian yang hanya melatihkan segi kognitif siswa, sehingga karakter ketuhanan siswa belum dapat terpenuhi, dan 6) tidak adanya peta konsep, petunjuk penggunaan dengan benar, kegiatan praktikum, dan glosarium.

Kebutuhan siswa dan guru mengenai bahan ajar yang yang tepat dan efektif dalam memberdayakan karakter religius siswa, maka perlu dikembangkan bahan ajar berupa modul IPA terpadu tipe Connected berbasis Iqra. Bahan ajar dalam bentuk modul ini berisikan sajian masalah konseptual dan kontekstual, sajian materi, lembar kerja, dan evaluasi. Modul dapat digunakan untuk belajar mandiri jika siswa ingin belajar sendiri, tetapi juga untuk melatihkan kemampuan sosial siswa dalam belajar. Modul digunakan dalam pembelajaran di kelas dan siswa melakukan kegiatan laboratorium dalam kelompokkelompok kecil. Modul pembelajaran berbasis Iqra menggunakan tema lingkungan pantai dengan memberdayakan karakter religius disajikan di bagian awal modul, penanaman hakikat ketuhanan dimulai dengan menanamkan rasa percaya adanya sesuatu yang bisa diteladani. Selanjutnya memotivasi peserta didik dengan sifat ketuhanan seperti kejujuran, keadilan, kebijaksanaan, sosial, kasih sayang dan sebagainya untuk memberi visi sesuai obyek yang akan dipelajari. Siswa kemudian dituntut untuk melakukan eksperimen dan/atau diskusi, selanjutnya mendorong peserta didik untuk menentukan jawaban dengan berbagai cara seperti amati, lakukan percobaan, baca, sederhanakan, modelkan dan sebagainya. Siswa secara berkelompok bekerja sama untuk melakukan eksperimen kemudian siswa mempresentasikan hasil eksperimennya. Proses dalam modul berbasis Iqra dapat memberdayakna karakter ketuhanan siswa.

Berdasarkan latar belakang masalah pada kenyataan di atas maka menjadi dasar 
dilakukan pengembangan Modul IPA Terpadu tipe Connected Berbasis Iqra. Tema dalam modul yaitu lingkungan pantai yang disajikan dengan mempertimbangkan kondisi siswa, kondisi sekolah dan prinsip-prinsip belajar. Pengembangan modul IPA terpadu tipe Connected diharapkan dapat memberdayakan karakter religius siswa SMP/ MTs kelas VII semester II.

\section{Metode Penelitian}

Penelitian ini menggunakan metode penelitian dan pengembangan (research and development). Pada penelitian dan pengembangan ini produk yang dihasilkan adalah Modul IPA Terpadu Tipe Connected Berbasis Iqra Tema Lingkungan Pantai untukMemberdayakan Karakter Religius Siswa SMP/MTs Kelas VII Semester II. Model penelitian yang digunakan adalah $\mathrm{R} \& \mathrm{D}$ (research and development) oleh Thiagarajan dan Sammel yakni model siklus 4-D yang meliputi: 1) pendefinisian (define), 2) perencanaan (design), 3) pengembangan (develop), dan 4) penyebarluasan (disseminate).

Desain eksperimen yang digunakan adalah one group pretest and postest, sehingga penelitian hanya melibatkan sekelompok subjek yang diberi pretest sebelum dikenai perlakuan, dan posttest setelah dikenai perlakuan untuk diketahui hasil akibat perlakuan tersebut.

Metode pengumpulan data yang digunakan pada penelitian dan pengembangan Modul IPA Terpadu Tipe Connected tema Lingkungan Pantai adalah tes, angket, observasi, dan wawancara. Teknik tes dilakukan dengan menggunakan instrumen penilaian aspek kognitif yang telah dianalisis menggunakan excel. Teknik angket dilakukan menggunakan instrumen angket kebutuhan, angket respon, lembar validasi, dan angket pemberdayaan karakter religius. Angket kebutuhan, respon, dan angket pemberdayaan karakter religius telah divalidasi oleh pembimbing penelitian. Teknik observasi dilakukan untuk memperoleh penilaian sikap, keterampilan siswa, keterlaksanaan sintaks pembelajaran, dan pemberdayaan karakter religius. Instrumen yang digunakan pada penilaian sikap, keterampilan, keterlaksanaan sintaks, dan pemberdayaan karakter religius disesuikan dengan indikator yang akan muncul dalam pembelajaran menggunakan skala Likert 4. Lembar observasi telah divalidasi oleh pembimbing. Teknik wawancara dilakukan secara tidak terstruktur pada tahap pendefinisian dan pengembangan.

Data yang diperoleh pada penelitian dan pengembangan Modul IPA Terpadu Tipe Connected Berbasis Iqra Tema Lingkungan Pantai untuk Memberdayakan Karakter Religius Siswa SMP/MTs Kelas VII Semester II adalah data validasi ahli (materi, media, dan bahasa Indonesia), praktisi pendidikan, dan teman sejawat, nilai pretest dan posttest, nilai sikap dan keterampilan, keterlaksanaan sintaks pembelajaran, angket respon, angket pemberdayaan karakter religius, serta angket diseminasi dan implementasi produk. Data validasi ahli, praktisi pendidikan, dan teman sejawat, angket respon, angket pemberdayaan karakter religius, serta angket diseminasi dan implementasi dianalisis menggunakan kategori skala 4 menurut teori Millah (2014). Nilai pretest dan posttest dinalisis dengan uji $n$-gain menurut persamaan Hake (1998). Nilai sikap, keterampilan, pemberdayaan karakter religius dianalisis dengan menggunakan tabulasi nilai yang dikonversi menjadi presentase.

\section{Hasil Penelitian dan Pembahasan}

\section{Deskripsi Data Hasil Penelitian}

Penelitian dan pengembangan Modul IPA Terpadu Tipe Connected Berbasis Iqra Tema Lingkungan Pantai dilakukan dengan menggunakan model 4-D oleh Thiagarajan dan Sammel (1974) dari tahapan 1 s.d. 4 yaitu (1) pendefinisian (define), (2) perencanaan (design), (3) pengembangan (develop), (4) penyebarluasan (Disseminate). Data hasil pengembangan pada setiap tahap adalah:

\section{Tahap Define}

Tahap Define dilakukan untuk mengidentifikasi masalah-masalah yang ada dalam pembelajaran dan dijadikan dasar untuk merancang produk penelitian berupa modul. 
Pada tahap ini dilakukan studi pendahuluan yang meliputi studi pustaka dan survei lapangan.

Hasil studi pustaka yang dilakukan diantaranya adalah menganalisis SK dan KD yang memungkinkan untuk dipilih sebagai acuan pengembangan modul pembelajaran. Analisis mengenai bahan ajar menunjukkan bahwa di sekolah masih menggunakan buku ajar yang terbatas, buku yang menunjang belajar siswa hanya buku BSE yang diterbitkan oleh Pusat Perbukuan Depdiknas, serta belum adanya buku ajar yang secara kontekstual berisi potensi lokal lingkungan sekitar siswa. Hasil survei lapangan menunjukkan bahwa 1) pembelajaran masih menggunakan metode ceramah dan kerja kelompok, 2) motivasi dan minat belajar siswa masih rendah, 3) siswa kurang aktif dalam mengemukakan maupun menanggapi pendapat, 4) kemampuan siswa dalam mengerjakan soal - soal masih belum kompleks 5) buku ajar yang digunakan guru dalam pembelajaran masih dari pemerintah dan LKS, sehingga belum ada buku ajar yang secara kontekstual berisikan tentang kearifan lokal daerah yaitu lingkungan pantai, 6) hasil belajar masih di bawah KKM, sehingga guru harus mengadakan remidiasi.

Hasil penelitian menuju pada kesimpulan bahwa untuk mencapai KKM pada tema lingkungan pantai dapat dikembangkan Modul IPA Terpadu Tipe Connected Berbasis Iqra. Pencapaian KKM meliputi aspek pengetahuan, sikap, dan keterampilan.

\section{Tahap Design}

Tahap design bertujuan untuk merancang dan membuat desain awal media pembelajaran berupa modul IPA terpadu berbasis Iqra dengan tema lingkungan pantai. Menurut Thiagarajan (1974) tahap design (perancangan) terdiri dari empat langkah yaitu penyusunan tes, pemilihan media, pemilihan format, dan rancangan awal. Pada tahap ini menghasilkan modul draf I yang merupakan desain awal modul pembelajaran IPA terpadu berbasis Iqra dengan tema lingkungan pantai.

Tahap penyusunan tes menggunakan tes berupa pretest dan posttest. Pada tahap pemilihan media, media yang dipilih dalam penelitian adalah modul IPA terpadu tipw
Connected berbasis Iqra tema lingkungan pantai yang berupa modul cetak. Pada tahap pemilihan format kriteria modul yang diadaptasi dari Mulyasa (2006) yang disusun berdasarkan komponen Iqra dan dimodifikasi dengan menambahkan karakter religius.

Tahap rancangan awal modul yang dikembangkan pada penelitian ini setelah menganalisis SK dan KD disusun judul dan langkah-langkah umum dalam modul maka dilakukan pemilihan format dan desain awal modul meliputi jenis dan ukuran huruf yang dipakai, ukuran kertas, margin, dan fitur pendukung untuk menambah ketertarikan siswa mempelajari modul.

\section{a. Draf I}

Draf I modul pembelajaran IPA terpadu tipe Connected berbasis Iqra tema lingkungan pantai terdiri dari tiga kegiatan pembelajaran. Dalam satu modul mewakili satu kompetensi dasar pada kajian asam basa garam, peranan kalor., dan pencemaran lingkungan.

\section{Tahap Develop}

Tahap develop merupakan tahap pengembangan produk. Tahapan ini terdiri dari tahapan validasi, uji coba terbatas, dan uji lapangan operasional. Pada tahap validasi, modul divalidasi oleh dua dosen ahli (ahli materi dan ahli media), dua guru IPA, dan dua teman sejawat. Validasi ini meliputi penilaian aspek materi dan aspek media. Data hasil perbaikan modul berdasarkan saran-saran dari validator disajikan pada tabel 2 .

Tabel 2. Hasil Masukan dari Validator

\begin{tabular}{|c|c|c|}
\hline Validator & Masukan & Revisi \\
\hline Dosen & $\begin{array}{l}\text {-Ditambahkan } \\
\text { tentang angin darat dan } \\
\text { angin laut yang sesuai } \\
\text { dengan tema } \\
\text {-Soal-soal pada uji } \\
\text { kompetensi terlalu sedikit } \\
\text {-Pada kata pengantar } \\
\text { kalimat Modul IPA terpadu } \\
\text { tipe webbed berbasis Iqra' } \\
\text { berulang sebanyak } 7 \text { (tujuh) } \\
\text { kali }\end{array}$ & $\begin{array}{l}\text {-Materi angin } \\
\text { darat dan angin } \\
\text { laut ditambahkan } \\
\text { pada modul } \\
\text {-Soal pada uji } \\
\text { ditambah } \\
\text {-Kalimat 'Modul } \\
\text { IPA terpadu tipe } \\
\text { webbed berbasis } \\
\text { Iqra' ditulis } 1 \\
\text { (satu) kali dan } \\
\text { diganti dengan } \\
\text { 'Modul ini' } \\
\text {-Kalimat } \\
\text { "..dipanaskan } \\
\text { dengan kompor" } \\
\text { diganti "..dengan } \\
\text { api” } \\
\text {-Melengkapi } \\
\text { konsep dengan } \\
\text { gambar. }\end{array}$ \\
\hline
\end{tabular}


JURNAL INKUIRI

ISSN: 2252-7893, Vol. 6, No. 3, 2017 (hal 113-126)

http://jurnal.uns.ac.id/inkuiri

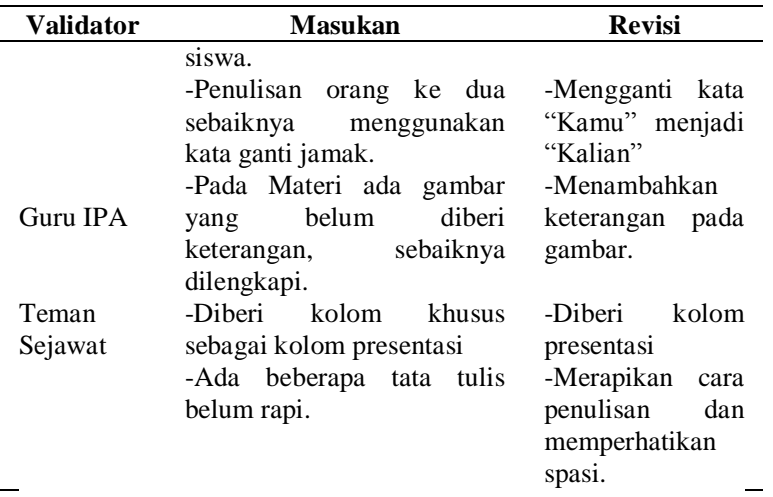

- Setelah Draf I modul direvisi kemudian divalidasi kembali oleh validator dengan hasil validasi dapat dilihat pada tabel 3 sampai dengan tabel 7

Tabel 3. Hasil Validasi Ahli Materi

\begin{tabular}{|c|c|c|}
\hline Aspek & $\begin{array}{c}\text { Skor } \\
\text { rata-rata }\end{array}$ & Kategori \\
\hline Konsep Dasar Materi & 3,33 & Baik \\
\hline Konsep Sub Materi Bahasan & 3,67 & Sangat Baik \\
\hline Konsep Gambar & 3,67 & Sangat Baik \\
\hline Penyajian Gambar & 3,33 & Baik \\
\hline Sistematika Penyampaian Materi & 3,67 & Sangat Baik \\
\hline $\begin{array}{l}\text { Relevansi Dengan } \\
\text { Sehari-hari }\end{array}$ & 3,33 & Baik \\
\hline $\begin{array}{l}\text { Relevansi Dengan Kredibilitas } \\
\text { Buku Sumber }\end{array}$ & 3,67 & Sangat Baik \\
\hline $\begin{array}{c}\text { Penggunaan Bahasa pada Materi } \\
\text { Rata-rata }\end{array}$ & $\begin{array}{l}3,67 \\
3,54\end{array}$ & $\begin{array}{l}\text { Sangat Baik } \\
\text { Sangat Baik }\end{array}$ \\
\hline
\end{tabular}

Berdasarkan hasil validasi ahli materi modul, diperoleh rata-rata dari keseluruhan aspek sebesar 3,54 yang dikategorikan "sangat baik" sehingga disimpulkan bahwa modul yang dikembangkan memiliki materi yang baik setelah memperbaiki revisi yang disarankan.

Tabel 4. Hasil Validasi Ahli Media

\begin{tabular}{lcc}
\multicolumn{1}{c}{ Aspek } & $\begin{array}{c}\text { Skor } \\
\text { rata-rata }\end{array}$ & Kategori \\
\hline Tampilan Umum & 3,43 & Sangat Baik \\
Penggunaan Bahasa Dalam Modul & 3,00 & Baik \\
Kejelasan Bahasa & 4,00 & Baik \\
Rata-rata & 3,48 & Baik \\
\hline
\end{tabular}

Berdasarkan hasil validasi ahli media, rata-rata keseluruhan aspek sebesar 3,48 dikategorikan "baik" sehingga dapat disimpulkan bahwa modul yang digunakan dari segi media adalah baik setelah memperbaiki revisi yang disarankan.

Tabel 5. Validasi Ahli Bahasa

\begin{tabular}{ccc}
\multicolumn{1}{c}{ Aspek } & $\begin{array}{c}\text { Skor } \\
\text { rata-rata }\end{array}$ & Kategori \\
& 3,67 & Sangat Baik \\
\hline Penggunaan Bahasa dalam Modul & 3,75 & Sangat Baik \\
Kejelasan Bahasa & 3,74 & Sangat Baik \\
\hline Rata-rata & & \\
\hline
\end{tabular}

Berdasarkan hasil validasi ahli bahasa, diperoleh rata-rata keseluruhan aspek sebesar 3,74 dikategorikan "sangat baik" sehingga dapat disimpulkan bahwa modul yang digunakan dari segi bahasa adalah baik setelah memperbaiki revisi yang disarankan.

Tabel 6. Hasil Validasi Praktisi Pendidikan (Guru IPA)

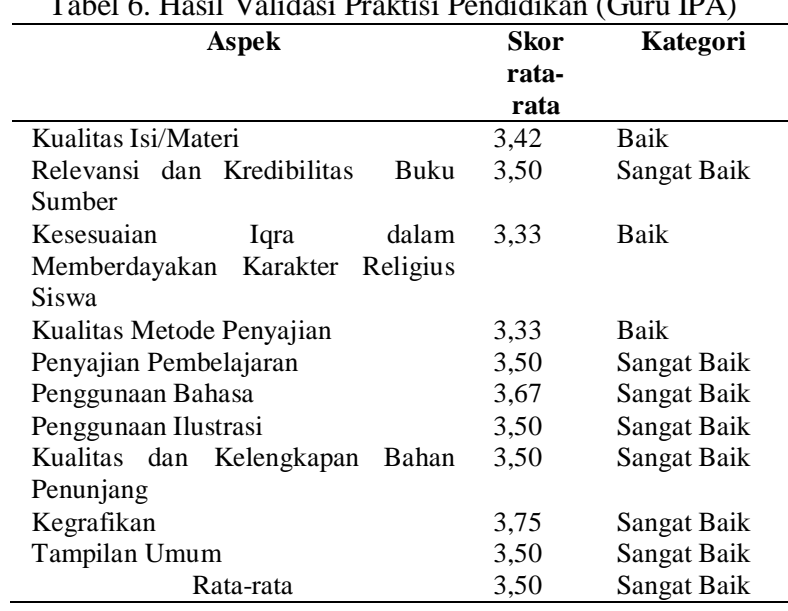

Berdasarkan hasil validasi oleh praktisi pendidikan, diperoleh rata-rata keseluruhan aspek sebesar 3,50 dan berada pada kategori "sangat baik", sehingga dapat disimpulkan bahwa modul yang digunakan menurut praktisi pendidikan adalah baik setelah memperbaiki revisi yang disarankan.

Tabel 7. Hasil Validasi Teman Sejawat

\begin{tabular}{|c|c|c|}
\hline Aspek & $\begin{array}{l}\text { Skor } \\
\text { rata- } \\
\text { rata }\end{array}$ & Kategori \\
\hline Kualitas Isi/Materi & 3,75 & Sangat Baik \\
\hline $\begin{array}{l}\text { Relevansi dan Kredibilitas Buku } \\
\text { Sumber }\end{array}$ & 3,83 & Sangat Baik \\
\hline $\begin{array}{llr}\text { Kesesuaian } & \text { Iqra } & \text { dalam } \\
\text { Memberdayakan } & \text { Karakter } & \text { Religius } \\
\text { Siswa } & & \end{array}$ & 3,67 & Sangat Baik \\
\hline Kualitas Metode Penyajian & 3,67 & Sangat Baik \\
\hline Penyajian Pembelajaran & 3,75 & Sangat Baik \\
\hline Penggunaan Bahasa & 3,83 & Sangat Baik \\
\hline Penggunaan Ilustrasi & 3,80 & Sangat Baik \\
\hline $\begin{array}{l}\text { Kualitas dan Kelengkapan Bahan } \\
\text { Penunjang }\end{array}$ & 3,75 & Sangat Baik \\
\hline Kegrafikan & 3,88 & Sangat Baik \\
\hline Tampilan Umum & 3,50 & Sangat Baik \\
\hline Rata-rata & 3,74 & Sangat Baik \\
\hline
\end{tabular}

Berdasarkan hasil validasi oleh teman sejawat, diperoleh rata-rata keseluruhan aspek 3,74 dikategorikan "sangat baik".

Hasil penilaian yang digunakan adalah validasi ahli media, ahli materi, ahli bahasa, praktisi pendidikan (Guru IPA), dan teman 
sejawat. Jika hasil penilaian oleh ahli > $62,50 \%$ sesuai dengan kelayakan modul menurut BSNP (Badan Standar Nasional Pendidikan) untuk setiap komponennya maka modul layak digunakan sebagai bahan ajar baru bagi siswa.

\section{b. Draf II}

Setelah draf I direvisi maka dihasilkan draf II yang telah direvisi berdasarkan masukan validator. Setelah itu peneliti melakukan uji coba terbatas yaitu peneliti melakukan uji coba pada 10 siswa kelas VIIB di SMP Institut Indonesia Kutoarjo untuk melihat keterbacaan modul yaitu dengan memberikan angket respon kepada siswa. Hasil uji coba terbatas dapat dilihat pada tabel 8 .

Tabel 8. Hasil Uji Coba Terbatas

\begin{tabular}{lcc}
\hline \multicolumn{1}{c}{ Aspek } & Skor rata-rata & Kategori \\
\hline Isi Modul & 3,63 & Sangat Baik \\
Penyajian & 3,60 & Sangat Baik \\
Bahasa/Keterbacaan & 3,67 & Sangat Baik \\
Rata-rata & 3,63 & Sangat Baik \\
\hline
\end{tabular}

Berdasarkan hasil kuisioner uji coba lapangan terbatas, diperoleh rata-rata dari keseluruhan aspek sebesar 3,63 berada pada kategori "sangat baik". Siswa pada uji coba terbatas juga memberikan saran pada angket yang dibagikan. Saran siswa pada uji coba terbatas yaitu penambahan gambar pada beberapa materi. Saran siswa pada uji terbatas direalisasikan dengan dilakukannya penambahan gambar pada materi yang perlu mendapat dukungan gambar.

\section{c. Draf III}

Draf III adalah hasil revisi II yang direvisi berdasarkan uji coba terbatas. Selanjutnya darf III ini digunakan untuk diimplementasikan kepada siswa kelas VIIA SMP Institut Indonesia Kutoarjo (uji lapangan operasional)

Uji lapangan operasional bertujuan untuk mengetahui peningkatan hasil belajar kognitif, afektif, dan psikomotorik serta pemberdayaan karakter religius setelah menggunakan modul IPA terpadu tipe Connected berbasis Iqra hasil pengembangan. Siswa terlebih dahulu diberikan pretest untuk mengetahui kemampuan awal siswa pada tema lingkungan pantai sebelum diberikan pembelajaran menggunakan modul, dan setelah pembelajaran menggunakan modul IPA terpadu tipe Connected berbasis Iqra selesai, siswa diberi posttest.

\section{d. Analisis Hasil}

Data hasil belajar kognitif yang diperoleh dari nilai pretest dan posttest pada tahap uji coba lapangan operasional meliputi nilai evaluasi dan nilai uji kompetensi, dapat dilihat pada tabel 9 .

Tabel 9.Deskripsi Data Hasil Belajar Kognitif Siswa

\begin{tabular}{ccccc}
\hline Jenis Tes & $\begin{array}{c}\text { Jumlah } \\
\text { Siswa }\end{array}$ & Mean & $\begin{array}{c}\text { Nilai } \\
\text { Maksimal }\end{array}$ & $\begin{array}{c}\text { Nilai } \\
\text { Minimal }\end{array}$ \\
\hline Pretest & 10 & 65,3 & 77,0 & 55,0 \\
Postest & 30 & 85,9 & 97,0 & 77,0 \\
\hline
\end{tabular}

Berdasarkan data hasil belajar kognitif siswa, diketahui bahwa rata-rata hasil belajar kognitif siswa sebelum diterapkan pembelajaran menggunakan modul sebesar 65,3 dengan standar deviasi 6,33 dan nilai minimum yang didapatkan 50,0, serta nilai maksimum 77. Rata-rata yang didapatkan berdasarkan hasil belajar kognitif siswa setelah diterapkannya pembelajaran menggunakan modul sebesar 85,9 dengan standar deviasi 5,81 dan didapatkan nilai minimum 77 , serta nilai maksimum 97, maka dapat disimpulkan bahwa modul IPA terpadu tipe Connected berbasis Iqra tema lingkungan pantai dapat meningkatkan hasil belajar kognitif siswa.

Berdasarkan hasil nilai pretest dan posttest, kemudian dapat digunakan untuk mengetahui efektivitas pembelajaran menggunakan penerapan modul dengan rumus $N$-gain ternormalisasi. Hasil $N$-gain ternormalisasi hasil belajar kognitif siswa diperoleh rata-rata sebesar 0,58. Menurut kriteria Hake (1998:1) besaran capaian nilai tersebut menunjukkan bahwa hasil belajar kognitif siswa dikategorikan "sedang".

Ketercapaian pemberdayaan nilai karakter religius dapat dilihat berdasarkan kriteria yang telah ditentukan dengan menggunakan angket. Jawaban angket yang dikategorikan ke dalam pernyataan Selalu (S), Sering (SR), Jarang (J), dan Tidak Pernah (TP). Angket dan lembar observasi merujuk pada 5 aspek religius menurut Glog dan Stark dalam Lies Arifah (2009:12) yakni Religious 
belief (aspek keyakinan), Religious practice (aspek peribadatan), Religious felling (aspek penghayatan), Religious knowledge (aspek pengetahuan), dan Religious effect (aspek pengamalan). Serta dilakukan dengan lembar observasi oleh tiga orang observer yang mengobservasi implementasi nilai karakter siswa di sekolah, data yang diperoleh juga dihitung dengan menggunakan persentase keidealan pada tabel 10 berikut:

Tabel 10. Hasil Pemberdayaan Karakter Religius

\begin{tabular}{ccc}
\hline Jumlah Siswa & Observasi (\%) & Angket (\%) \\
\hline 30 & 80,0 & 90,3 \\
\hline
\end{tabular}

Berdasarkan tabel 10 diketahui bahwa rata-rata karakter religius dari angket siswa yaitu 90,3\% yang memiliki kategori "sangat baik", serta dari lembar observasi oleh tiga orang observer diketahui rata-rata pemberdayaan karakter religius pada saat pembelajaran memiliki ratarata nilai yakni $80,0 \%$ yang memiliki kategori "baik'.

\section{Tahap Disseminate}

Diseminasi dan implementasi dilakukan untuk memperkenalkan modul IPA yang dikembangkan ke SMP/MTs di Kota Purworejo. Data yang diperoleh dari diseminasi dan implementasi berupa tanggapan, saran, dan masukan dari guru IPA mengenai modul IPA terpadu, yang diharapkan Modul IPA terpadu berbasis Iqra pada tema lingkungan pantai dapat diterapkan sebagai bahan ajar baru untuk guru dan siswa. Tanggapan guru terhadap modul IPA Terpadu menunujukkan reaksi positif yakni modul pembelajaran sudah baik dan sudah bisa digunakan sebagai bahan ajar baru. Hasil kuisioner pada tahapan diseminasi dan implementasi modul IPA tertulis pada tabel 11 berikut;

Tabel 11. Hasil Kuisioner Tahapan Diseminasi dan Implementasi Produk

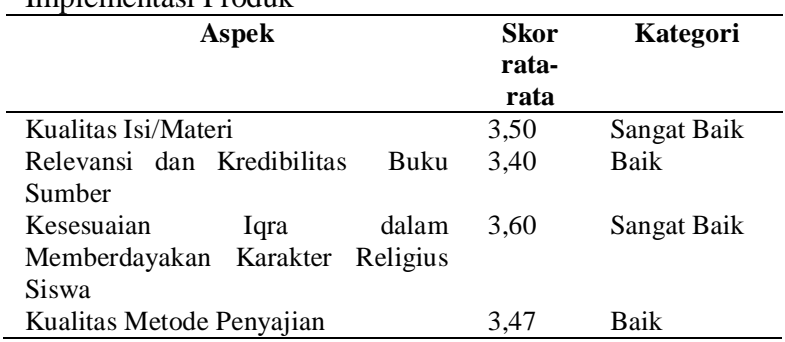

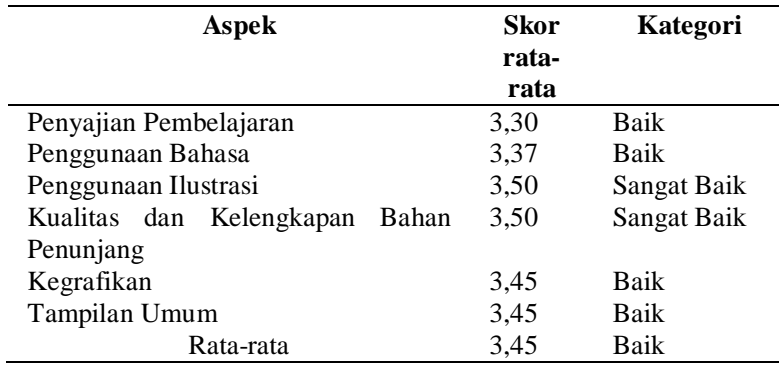

Berdasarkan hasil kuisioner pada tahap diseminasi dan implementasi produk oleh lima guru IPA di Kota Purworejo yang tertulis pada Tabel 11, diperoleh rata-rata dari keseluruhan aspek sebesar 3,45 dikategorikan " baik".

\section{Pembahasan}

Penelitian ini merupakan jenis penelitian pengembangan pada bidang pendidikan. Tempat penelitian di SMP Institut Indonesia Kutoarjo. Sampel yang digunakan adalah satu kelas, menggunakan desain uji coba lapangan One-Group Pretest-Posttest Desain, menggunakan satu kelas dengan penerapan modul IPA berbasis Iqra pada tema lingkungan pantai.

Produk yang dihasilkan dalam penelitian pengembangan ini berupa modul cetak berbasis Iqra yang dilengkapi dengan Rencana Pelaksanaan Pembelajaran (RPP) bagi guru sebagai petunjuk dalam pelaksanaan pembelajaran di lapangan dan Lembar Kerja Siswa (LKS) bagi siswa.

Peneliti menyusun produk pengembangan pembelajaran berupa modul cetak kemudian dilanjutkan dengan menguji kelayakan dan efektivitas produk modul cetak tersebut. Hal ini sesuai dengan tahapan penelitian pengembangan yang mengacu pada model Research and Development (R\&D) siklus 4-D dari Thiagarajan dengan langkah-langkah dalam research and development (R\&D) antara lain: 1) Define (pendefinisian), 2) Design (Perancanaan), 3) Develop (Pengembangan), Disseminate (penyebaran).

\section{Tahap Define}

Tahapan ini dilakukan dengan menyebarluaskan angket kepada guru IPA dan siswa SMP Institut Indonesia Kutoarjo. Berdasarkan hasil pengisian angket 
didapatkan hasil analisis mengenai bahan ajar yang digunakan guru ketika proses pembelajaran, bahwa materi ajar dalam buku ajar guru masih terlalu luas, sehingga belum mengoptimalkan karakter siswa melalui kegiatan pembelajaran. Buku yang digunakan adalah BSE yang diterbitkan oleh Pusat Perbukuan Depdiknas, serta tidak melakukan kegiatan eksperimen. Karena kegiatan eksperimen tidak pernah dilakukan, maka Iqra siswa belum bisa terlatih yang berakibat pada rendahnya kemampuan siswa dalam "Iqra" atau membaca alam baik dari aspek Ketuhanan maupun pengetahuan, sehingga potensi siswa belum dapat dimanfaatkan secara optimal. Buku ajar yang digunakan belum disesuaikan dengan potensi, karakteristik siswa, potensi sekolah, dan lingkungan sekitarnya. Millah (2012:20) mengemukakan pandangan yang sesuai, menurutnya berdasarkan survei terhadap bahan ajar yang ada di pasaran masih terdapat beberapa kekurangan, yaitu belum membuat siswa mampu memecahkan masalah dalam kehidupan sehari-hari.

\section{Tahap Design}

Setelah dilakukan analisis pada penelitian studi pendahuluan, kemudian ditentukan perencanaan pengembangan produk yang sesuai untuk memenuhi kebutuhan dan spesifikasi produk yang berkaitan dengan proses pembelajaran. Berdasarkan hasil tahap studi pendahuluan maka ditentukan pada penelitian pengembangan ini, spesifikasi produk yang akan dikembangkan adalah Modul IPA terpadu tipe webbed pada tema lingkungan pantai berbasis Iqra sebagai upaya untuk memberdayakan karakter religius dan memecahkan masalah dalam kehidupan sehari - hari. Komponen tersebut menjadi inti dan jiwa dari modul, dan dapat menjadikan karakteristik modul berbeda dengan modul lainnya.

Iqra dipilih karena aktivitas pada sintaks Iqra merupakan bagian metode ilmiah yang menjadi inti dalam pembelajaran IPA khususnya IPA terpadu level SMP/MTs. Iqra yang diintegrasikan dengan modul, memotivasi siswa untuk menemukan sendiri konsep IPA melalui proses ilmiah. Hal ini secara tidak langsung dapat melatihkan karakter religius siswa, sehingga siswa dapat dengan mudah mengaplikasikan konsep dalam kehidupan sehari - hari maupun dalam pemecahan soal uji kompetensi. Ridlo (2005) menyatakan pendapat yang sesuai yakni dengan pembelajaran model Iqra peserta didik diajak untuk mendengarkan suara-suara alam, mengagumi ciptaan Tuhan, mengekplorasi lingkungan, menyatukan perasaan dengan alam sehingga peserta didik tidak hanya mengerti tetapi terasah personal, sosial dan seninya.

\section{Tahap Develop}

Tahap develop merupakan tahap pengembangan. Tahapan ini terdiri dari tahapan validasi, uji coba terbatas, dan uji lapangan operasional. Pada tahap validasi, modul dan instrumen terlebih dahulu dikonsultasikan kepada pembimbing untuk kemudian divalidasi oleh 3 dosen ahli, satu praktisi pendidikan (guru IPA), dan dua teman sejawat yang akan diambil datanya mengenai penilaian, pendapat dan saran terkait modul, yang meliputi aspek isi, aspek metode penyajian, aspek bahasa, aspek ilustrasi, aspek kelengkapan, aspek fisik serta aspek keterlaksanaan. Modul yang telah divalidasi berkategorikan sangat baik tetapi masih memerlukan perbaikan. Perbaikan disesuaikan dengan pendapat, saran dari ahli dan praktisi agar modul yang dikembangkan menjadi lebih relevan dan layak untuk diujicobakan pada tahapan selanjutnya.

Modul yang dikembangkan diasumsikan layak berdasarkan penilaian seluruh aspek menurut validator ahli, praktisi pendidikan, dan teman sejawat. Bahan ajar yang layak digunakan dengan ktiteria baik apabila bahan ajar ditulis dengan menggunakan bahasa yang baik dan mudah dipahami, disajikan secara menarik dilengkapi dengan gambar dan keterangan-keterangannya, isi buku juga menggambarkan sesuatu berdasarkan dengan ide penulisnya (Depdiknas, 2008:12).

Berdasarkan hasil validasi dari tabel 3 sampai tabel 7 kemudian dilakukan analisis perhitungan presentase kelayakan modul. Sesuai dengan perhitungan tersebut menunjukkan bahwa presentase kelayakn yang didapatkan $>62,5 \%$, maka dapat 
disimpulkan bahwa modul layak digunakan. Setelah modul layak digunakan maka dilakukan uji coba terbatas. Uji coba terbatas dilaksanakan di SMP Institut Indonesia dengan jumlah siswa sebanyak sepuluh siswa, data diperoleh dari angket tanggapan siswa terhadap modul yang dikembangkan. Uji coba lapangan terbatas bertujuan untuk mendapatkan penilaian, saran, dan tanggapan dari siswa terhadap modul IPA terpadu yang dikembangkan, data yang didapatkan kemudian dirata-rata. Hasil uji coba terbatas menunjukkan skor rata - rata 3,67 dengan kategori modul "sangat baik", sehingga modul sudah baik untuk digunakan.

Tahap selanjutnya uji lapangan operasional dilakukan setelah melakukan perbaikan pada modul berdasar saran dan masukan siswa pada uji terbatas. Tahap uji lapangan operasional dilakukan kepada 30 siswa kelas VII A di SMP Institut Indonesia Kutoarjo. Proses pembelajaran dengan menggunakan modul IPA terpadu tipe Connected yang dikembangkan yaitu modul berbasis Iqra pada tema lingkungan pantai. Penilaian modul di laksanakan selama kegiatan pembelajaran. Data yang diambil berupa penilaian (kognitif, psikomotor, afektif), pemberdayaan karakter religius dan tanggapan/respon siswa terhadap pembelajaran selama menggunakan modul.

Data hasil belajar kognitif yang diperoleh dari uji lapangan operasional dapat dilihat pada tabel 9 yakni data Pre-Test dan PostTest. Hasil belajar kognitif berdasarkan analisis $\mathrm{N}$-gain diketahui bahwa kenaikan hasil belajar kognitif berkategotikan "tinggi", sehingga menunjukkan bahwa nilai pretest dan posttest terdapat perbedaan. Pemberdayaan karakter religius siswa dilakukan pada kegiatan pembelajaran dan akhir pertemuan dengan menggunakan Angket pemberdayaan karakter religius. Melalui observasi oleh tiga orang observer pemberdayaan karakter religius pada setiap pertemuan mengalami kenaikan dengan hasil rata-rata presentase keseluruhan pertemuan adalah 90,3\% yang memiliki kriteria "sangat baik". Serta angket pemberdayaan karakter religius dengan prosentase $80,0 \%$ yang memiliki kriteria "Baik". Hal tersebut menujukkan bahwa saat proses pembelajaran siswa berusaha memberdayakan karakter religius yang mereka miliki dengan mengaitkan antara materi dengan aktivitas eksperimen dan pembelajaran yang mereka alami. Penilaian modul setelah kegiatan pembelajaran dilakukan siswa dengan menggunakan angket. Data hasil analisis nilai rata - rata angket mendapat kriteria "sangat baik". Selain memberikan tanggapan melalui angket, siswa juga memberikan tanggapan/ komentar terhadap produk pengembangan modul IPA berbasis Iqra pada tema lingkungan pantai yang telah digunakan selama pembembelajaran, saran serta komentar siswa digunakan dalam penyempurnaan modul

\section{Tahap Disseminate}

Setelah revisi tahap akhir pada produk pengembangan maka dilakukan tahap diseminasi dan implementasi produk, tahap ini dilaksanakan di SMP di Kota Purworejo. Penyebaran dilakukan antara lain di SMP N 5 Purworejo, SMP N 14 Purworejo, SMP N 16 Purworejo, SMP N 28 Purworejo dan SMP Muhammadiyah Jono. Berdasar umpan balik dan tanggapan pada tabel 11 dapat diketahui bahwa guru memberikan respon positif terhadap pengembangan modul cetak pada tema lingkungan pantai berbasis Iqra sebagai upaya untuk memberdayakan karakter religius siswa, modul diasumsikan layak dan efektiv digunakan sebagai acuan pembuatan modul dengan materi yang berbeda.

\section{Kesimpulan dan Rekomendasi}

Kesimpulan penelitian dan pengembangan Modul IPA Terpadu Tipe Connected Berbasis Iqra Tema Lingkungan Pantai untuk Memberdayakan Karakter Religius Siswa SMP/MTs Kelas VII Semester II dengan karakteristik pengembangan Modul IPA yaitu menggunakan metode Research and Development oleh Thiagarajan dan Sammel (1974) dengan tahap 4-D yaitu pendefinisian (define), perancangan (design), pengembangan (develop), dan penyebarluasan (disseminate) 
yang dapat menghasilkan produk yang divalidasi dan diuji coba.

Kelayakan modul IPA terpadu tipe Connected berbasis Iqra setelah dilakukannya uji coba produk awal, uji coba lapangan terbatas, uji lapangan operasional, dan diseminasi serta implementasikan, modul didapatkan rata-rata persentase $89,4 \%$ dan dikategorikan "Sangat Baik, sehingga modul layak untuk digunakan.

Modul IPA terpadu tipe webbed berbasis Iqra efektiv digunakan sebagai bahan ajar baru, efektivitas modul didasarkan atas hasil perhitungan $\mathrm{N}$-gain sebesar 0,58 yang dikategorikan "sedang", serta pencapaian KKM sebesar 96,7\% yang dikategorikan "sangat baik". Sedangkan hasil perhitungan pemberdayaan karakter religius siswa didapatkan rata-rata keseluruhan nilai sebesar $85,2 \%$ yang dikategorikan "sangat baik" sehingga karakter religius dapat terberdayakan.

Berdasarkan proses dan kesimpulan yang diperoleh, saran serta perbaikan perlu dilakukan agar pemanfaatan produk bisa menjadi lebih baik lagi antara lain:1) karakter religius siswa dalam pembelajaran IPA wajib dipahami oleh guru sebagai pelaksana dan perencana kegiatan pembelajaran, 2) hasil penelitian ini hanya dilaksanakan pada siswa SMP Institut Indonesia Kutoarjo, sehinggaperludilakukan penelitian di sekolah yang lain untuk mendapatkan data yang bervariasi, 3) modul IPA terpadu tipe Connected berbasis Iqra menekankan pada kegiatan eksperimen, sehingga diperlukan adanya sarana dan prasarana yang dapat menunjang kegiatan eksperimen seperti alat dan bahan yang digunakan dalam kegiatan praktikum serta pemilihan kegiatan praktikum yang tepat, 4) penggunaan dan pengembangan modul IPA terpadu tipe Connected berbasis Iqra disarankan untuk dimanfaatkan secara optimal oleh guru sesuai materi yang diterapkan, 5) penggunaan modul pembelajaran harus memperhatikan alokasi waktu agar seluruh kegiatan pembelajaran terlaksana sesuai dengan yang tertera pada perangkat pembelajan, 6) pemanfaatan modul IPA terpadu tipe Connected berbasis Iqra sebaiknya didiseminasikan kepada semua guru
IPA SMP/MTs serta disosialisasikan pada pertemuan - pertemuan ilmiah seperti MGMP, 7) penelitian pengembangan produk modul IPA terpadu tipe Connected berbasis Iqra dikembangkan pada SK dan KD lain serta pada tema yang lain, 8) aspek psikomotor dan afektif diintegrasikan dalam pembelajaran yang dikembangkan lebih banyak lagi, dan 10) modul IPA terpadu tipe Connected berbasis Iqra dapat digunakan sebagai penunjang bahan ajar yang baru di sekolah, namun perlu keterampilan dan kreasi dalam pembuatan modul, validasi dari para ahli dan praktisi pendidikan, serta berbagai pelaksanaan uji coba terhadap modul yang dikembangkan supaya didapatkan modul yang baik dan layak digunakan dalam proses pembelajaran, 11) kegiatan pengujian efektivitas dalam kegiatan penelitian yang berkaitan dengan modul hasil pengembangan yang lebih mendalam dapat dibandingkan dengan modul lain sebagai peningkatan hasil belajar siswa.

\section{Daftar Pustaka}

Arikunto, S.(2006). Dasar-Dasar Evaluasi Pendidikan. Jakarta: PT. Bumi Aksara.Depdiknas. (Peraturan Menteri Pendidikan Nasional Republik Indonesia Nomor 22 tahun 2006 tentang Standar Isi untuk Satuan Pendidikan Dasar dan Menengah).

Fogarty, $\quad$ R. (1991). The Mindful School: How to Integrate the Curricula.Illinois:IRI /Skylight Publishing, Inc.

Hamid, Ahmad Abu. (2012). Penerapan Pendekatan Generik dan Metode Iqra dalam Pembelajaran Fisika dapat Menumbuhkembangkan Karakter Murid. Makalah disajikan dalam Seminar Nasional Penelitian, Pendidikan, dan Penerapan MIPA, di FMIPA UNY.

Muhaimin. (2013). Rekonstruksi pendidikan Islam dari Paradigma Pengembangan, Manajemen Kelembagaan, Kurikulum hingga Strategi Pembelajaran.Jakarta:Raja Grafindo Persada.

Mulyasa, Enco. (2010). Kurikulum Tingkat Satuan Pendidikan: Sebuah Panduan Praktis. Bandung: Remaja 
ISSN: 2252-7893, Vol. 6, No. 3, 2017 (hal 113-126)

http://jurnal.uns.ac.id/inkuiri

Rosdakarya.

Purwanto, $\quad$ Agus. (2011). Sains dan Pembentukan Karakter. Makalah disajikan dalam Seminar Nasional Peran Sains, Teknologi dan Budaya dalam Membangun Karakter Bangsa, di UIN Sunan Kalijaga Yogyakarta.

Stevenson, N. (2006). Young Person's Character Handbook. Indianapolis: JIST Publishing. Sukardjo. (2005). Evaluasi Pembelajaran Sains. Yogyakarta: Program Pascasarjana (PPs) UNY.

Sukardjo, Lis Permana Sari.(2009). Metodologi Penelitian Pendidikan Kimia. Yogyakarta:FMIPA UNY.

Tim Puslitjaknov. (2008). Metode Penelitian Pengembangan. Jakarta: Puslitjaknov Balitbang Depdiknas.

Triagrarajan Semmel.(1974). Instructional Development for Training Teachers Of Exceptional Children. Mineapoli :Minnecota.

Trianto. (2007). Model Pembelajaran Terpadu. Jakarta: Prestasi Pustaka.

Trianto. (2010). Model Pembelajaran Terpadu: Konsep, Strategi, dan Implementasinya dalam Kurikulum Tingkat Satuan Pendidikan (KTSP). Jakarta: Bumi Aksara.

Zamroni. (2011). Strategi dan Model Implementasi Pendidikan Karakter di Sekolah, Pendidikan Karakter dalam Perspektif Teori dan Praktik. Yogyakarta: UNY Press. 
JURNAL INKUIRI

ISSN: 2252-7893, Vol. 6, No. 3, 2017 (hal 113-126)

http://jurnal.uns.ac.id/inkuiri 